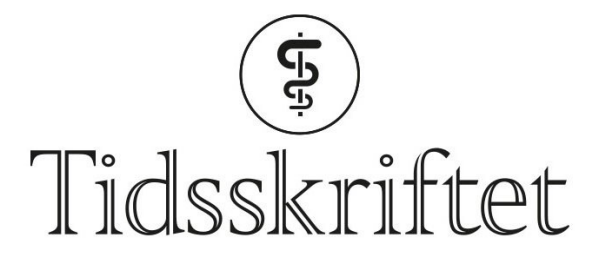

DEN NORSKE LEGEFORENING

\title{
Nytt legemiddel mot parasittsykdom i lever
}

FRA ANDRE TIDSSKRIFTER

KRISTOFFER BRODWALL

Barne- og ungdomsklinikken Haukeland universitetssykehus

Et nytt legemiddel mot sørøstasiatisk leverikte gir færre bivirkninger og nesten like god effekt som det som tidligere har vært eneste behandlingsmulighet.

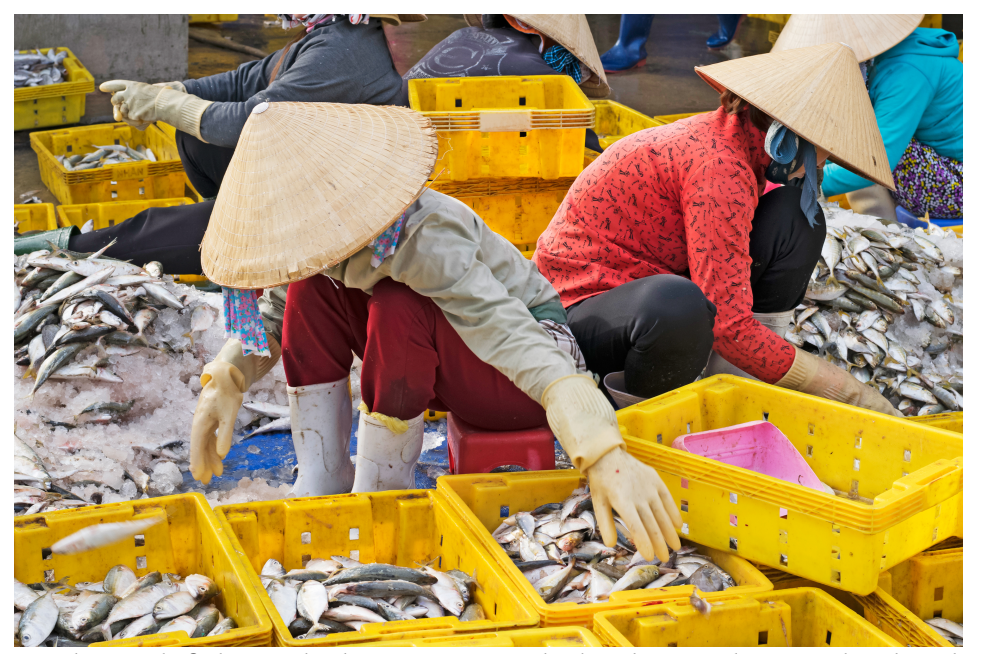

Tradisjonelt fiskemarked $i$ sørøstasiatiske land. Leverikte er utbredt i Thailand, Kambodsja og Laos, der vanligste smittemåte er inntak av fisk. Illustrasjonsfoto: FabVietnam Photography/iStock

Leverikte er en samlebetegnelse på parasittsykdommer forårsaket av trematoder som setter seg i lever og galleveier hos pattedyr. Sørøstasiatisk leverikte skyldes Opisthorchis viverrini, som kan forårsake alvorlig leversykdom, muligens også kreft i galleveiene. Sykdommen er utbredt i Thailand, Kambodsja og Laos med anslagsvis 10 millioner infiserte mennesker. Vanligste smittemåte er inntak av fisk.

Den eneste tilgjengelige behandlingen mot sørøstasiatisk leverikte er praziquantel. I en fersk studie ble effekten av et nytt legemiddel, tribendimidine, sammenlignet med effekten av praziquantel (1). Om lag 6oo pasienter fra Laos med påvist infeksjon med O. viverrini ble randomisert til behandling med ett av disse legemidlene. Av dem som fikk tribendimidine ble 93,6\% kurert, mot 97,3\% av dem som fikk praziquantel (effektforskjell 3,8 prosentpoeng; $95 \%$ KI o,4-7,1). Forskjellen var liten og innenfor den forhåndsdefinerte grensen for ikkeunderlegenhet (non-inferiority). Begge legemidlene reduserte mengden parasittegg med over $99 \%$. 
Pasientene som fikk tribendimidine hadde signifikant færre bivirkninger enn dem som fikk praziquantel. Protokollen tilsa behandling med to doser praziquantel, men én av seks tok ikke den andre dosen pga. bivirkninger. I tillegg hadde tribendimidine signifikant bedre effekt på koinfeksjoner med andre parasitter, slik som hakeorm. Studien tyder på at tribendimidine kan være et godt behandlingsalternativ mot sørøstasiatisk leverikte, særlig i befolkningsrettet massebehandling, der mengde utskilte egg og pasientenes etterlevelse er viktig.

\section{LITTERATUR:}

1. Sayasone S, Keiser J, Meister I et al. Efficacy and safety of tribendimidine versus praziquantel against Opisthorchis viverrini in Laos: an open-label, randomised, non-inferiority, phase 2 trial. Lancet Infect Dis 2018; 18: 155 - 61. [PubMed][CrossRef]

Publisert: 4. mai 2018. Tidsskr Nor Legeforen. DOI:10.4045/tidsskr.18.0134

(C) Tidsskrift for Den norske legeforening 2020. Lastet ned fra tidsskriftet.no 